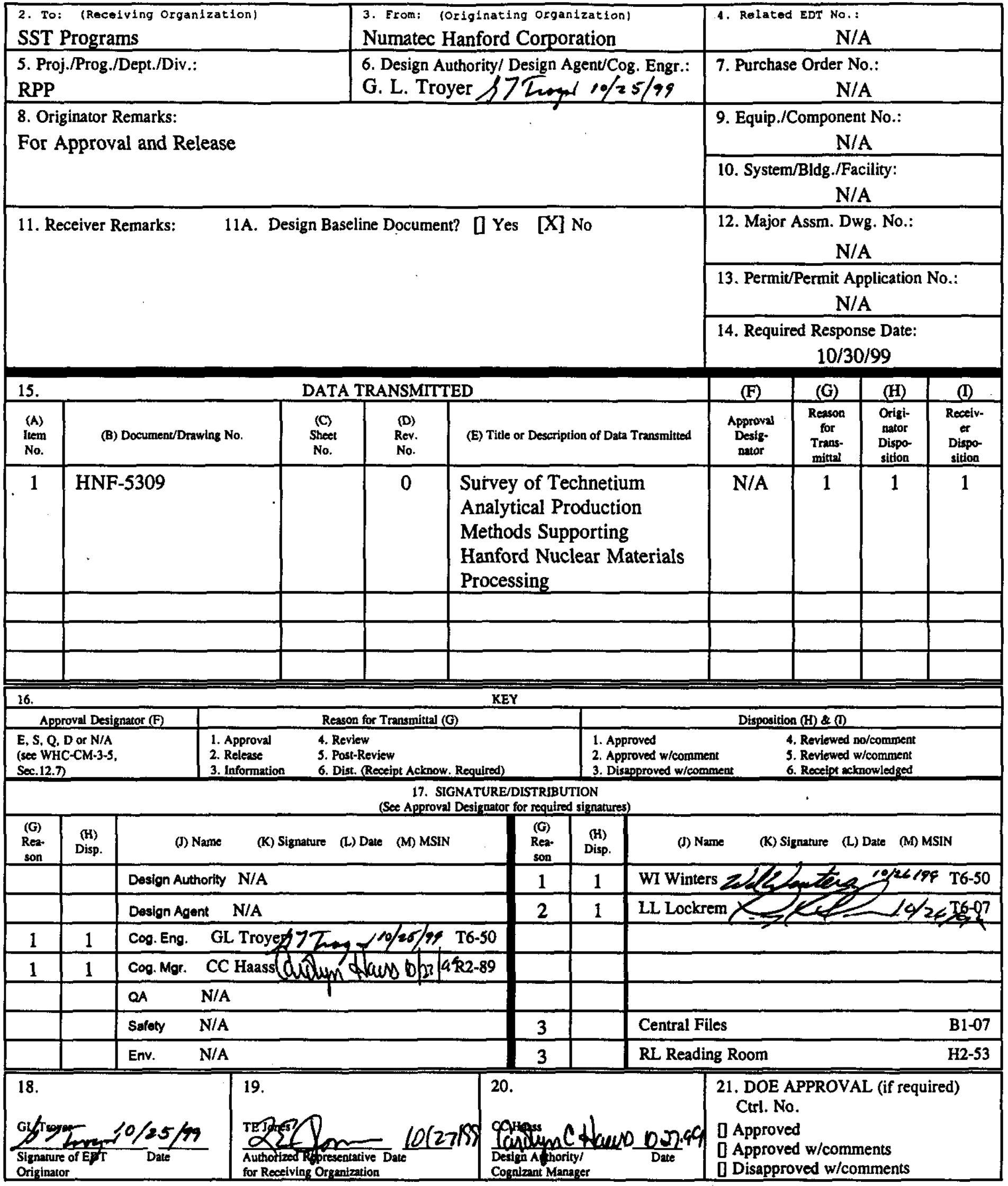




\section{Survey of Technetium Analytical Production Methods Supporting Hanford Nuclear Materials Processing}

G. L. Troyer and W. I. Winters

Numatec Hanford Corporation, Richland, WA 99352

U.S. Department of Energy Contract DE-AC06-96RL13200

$\begin{array}{llll}\text { EDT/ECN: } & 626586 & \text { UC: } & 2000 \\ \text { Org Code: } & 88200 & \text { Charge Code: } 102320 / E H 00 \text { ^ H M L M O } 351 \\ \text { B\&R Code: } & \text { EW02J1160 } & \text { Total Pages: } 26\end{array}$

Key Words: tank waste, sludge, technetium, analysis, pertechnetate, liquid scintillation

Abstract: This document provides a historical survey of analytical methods used for measuring ${ }^{99} \mathrm{Tc}$ in nuclear fuel reprocessing materials and wastes at Hanford. Method challenges including special sludge matrices tested are discussed. Special problems and recommendations are presented.

TRADEMARK DISCLAIMER, Reference herein to any specific comercial product, process, or service by trade name, trademark, manufacturer, or otherwise, doss not necessarily constitute or imply its endorsement, recommendation, or favoring by the United states Government or any agency thereof or its contractors or subcontractors.

Printed in the United States of America. To obtain coples of this document, contact: Document Control Services, P.O. Box 950, Mailstop H6-08, Richland WA 99352, Phone (509) 372-2420; Eax (509) 376-4989.
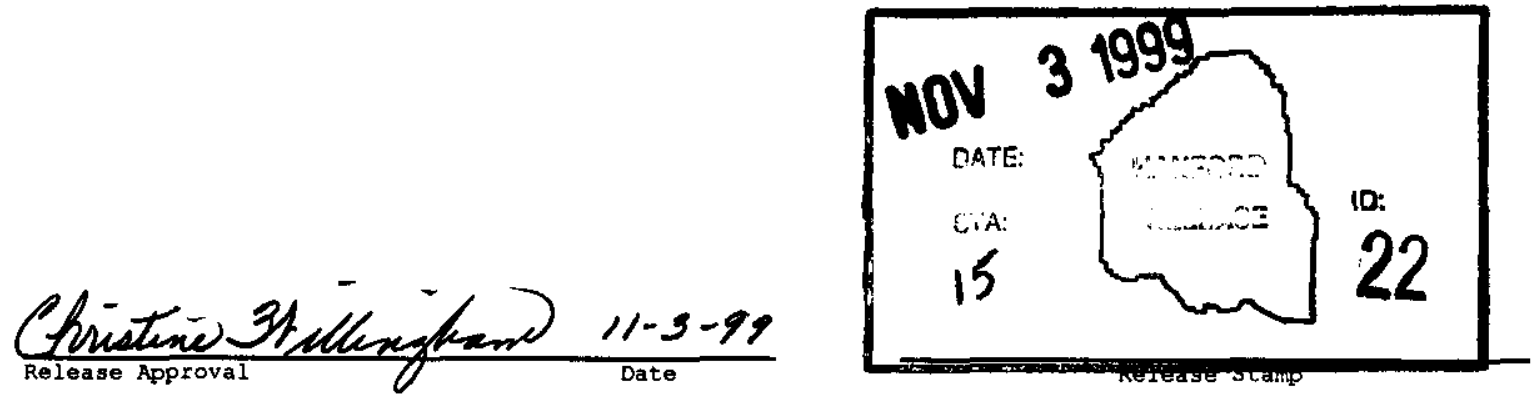
HNF-5309, Rev 0. October 20, 1999

\section{Survey of Technetium Analytical Production Methods \\ Supporting Hanford Nuclear Materials Processing}

Prepared by

G. L. Troyer

W. I. Winters

Numatec Hanford Corporation

Richland WA 99352

October 20, 1999 


\section{Table of Contents}

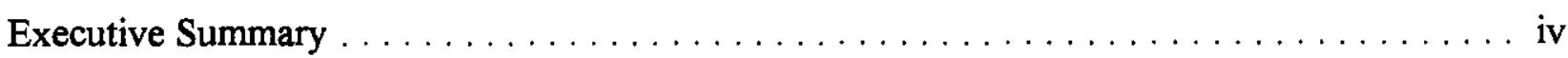

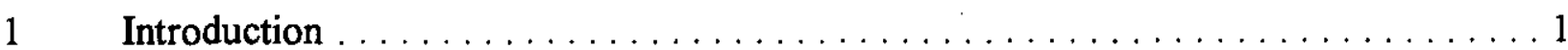

2 Summary of Hanford Technetium Analytical Methods $\ldots \ldots \ldots \ldots \ldots \ldots \ldots$

2.1 Hanford Technetium Analytical Methods $\ldots \ldots \ldots \ldots \ldots \ldots \ldots \ldots$

2.1.1 Tributyl Phosphate (TBP) Tc Method ................... 2

2.1.2 Cyclohexanone Tc Method ........................ 3

2.1.3 Tetrapropylammonium Hydroxide (TPAOH) Tc Method .......... 3

2.1 .4 Aliquat-336 $\mathrm{Tc}$ Method ........................ 4

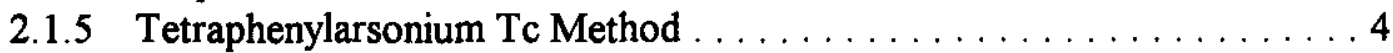

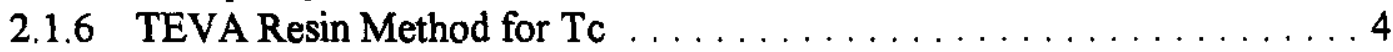

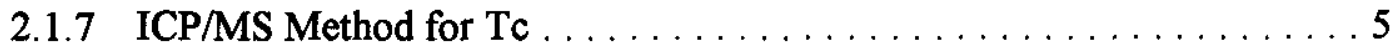

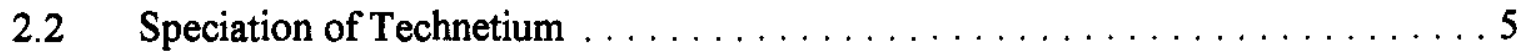

3 Technetium Analyses for Sample Exchange and Evaluation (SEE) Program . . . . . . 6

3.1 SEE Technetium Methods $\ldots \ldots \ldots \ldots \ldots \ldots \ldots \ldots \ldots \ldots \ldots \ldots \ldots$

3.2 SEE Phase I Technetium Results $\ldots \ldots \ldots \ldots \ldots \ldots \ldots \ldots \ldots \ldots$

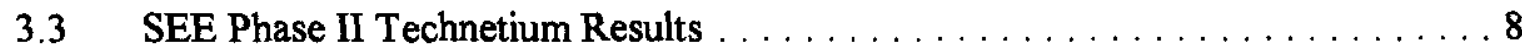

3.4 SEE Phase III Technetium Results . . . . . . . . . . . . . . . . . . . . . 8

3.5 SEE Phase IV and V Technetium Results $\ldots \ldots \ldots \ldots \ldots \ldots \ldots \ldots$

3.6 SEE Program Conclusion . . . . . . . . . . . . . . . . . . . . 9

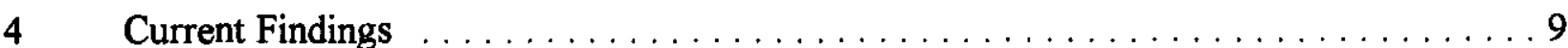

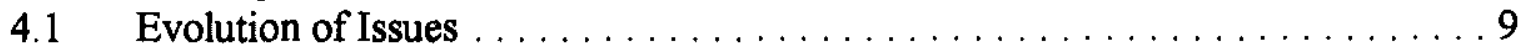

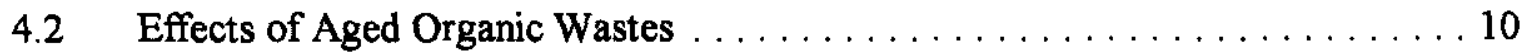

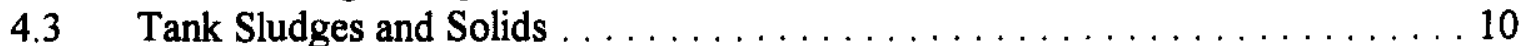

4.3.1 AX-104 Sludge Heel . . . . . . . . . . . . . . . . . . . . . . 10

4.3.2 C-104 Sludge . . . . . . . . . . . . . . . . . . . . . . . . 12

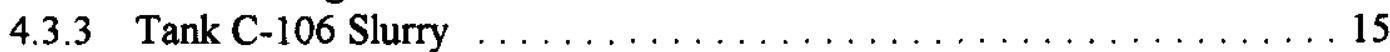

4.3.4 Additional Sludge Washing Performance ................ 15

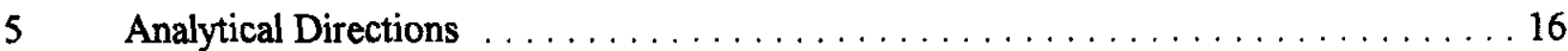

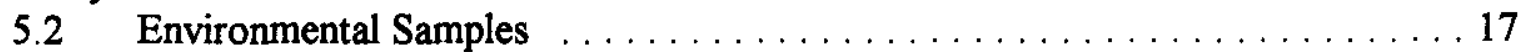

5.3 High Level Tank Supernates $\ldots \ldots \ldots \ldots \ldots \ldots \ldots \ldots \ldots \ldots \ldots \ldots \ldots$

5.3 .1 Aqueous Supernates $\ldots \ldots \ldots \ldots \ldots \ldots \ldots \ldots \ldots \ldots \ldots \ldots \ldots$

5.3 .2 Organic Supernates $\ldots \ldots \ldots \ldots \ldots \ldots \ldots \ldots \ldots \ldots \ldots \ldots \ldots$

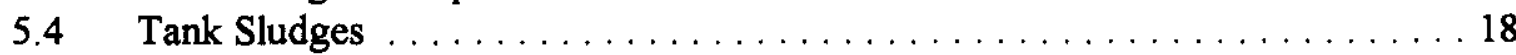

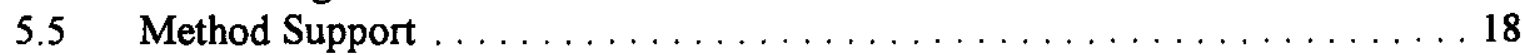


$5.6 \quad$ Tracers and Spikes $\ldots \ldots \ldots \ldots \ldots \ldots \ldots$

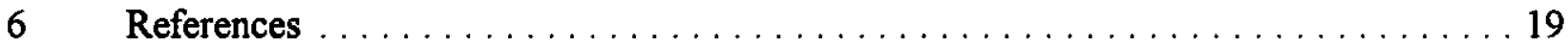

\section{List of Tables}

Table 1. Hanford Radiochemical Technetium Methods $\ldots \ldots \ldots \ldots \ldots \ldots \ldots \ldots$

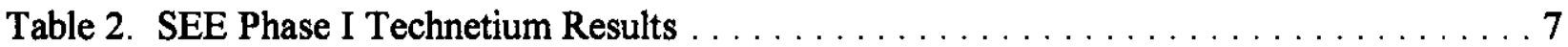

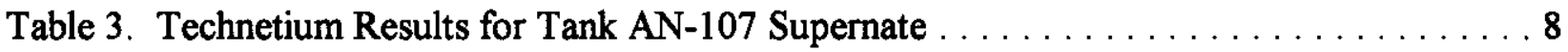

Table 4. $\left[{ }^{99} \mathrm{Tc}\right]$ Analysis Comparison for Organic Complex Supernate Samples . . . . . . . . . 9

Table 5. Results of Tank Supernate Sample Comparisons $-{ }^{99} \mathrm{Tc} \ldots \ldots \ldots \ldots \ldots \ldots \ldots$

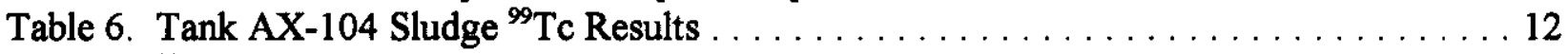

Table 7. ${ }^{99} \mathrm{Tc}$ Results for C-104 Sludge Sample S98T002049 . . . . . . . . . . . . . . . . . 12

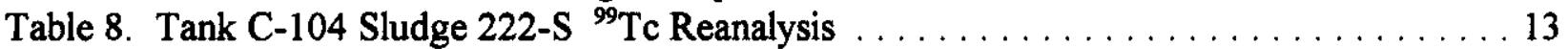

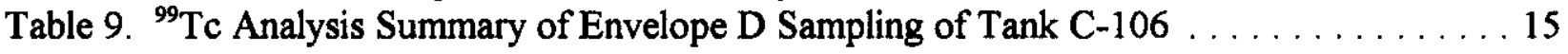

Table 10. Technetium Response to Caustic Washing and Leaching . . . . . . . . . . 16

\section{List of Figures}

Figure 1. Hanford chemical processing relationship to technetium analytical method development

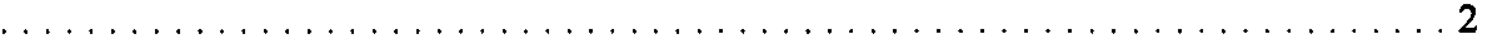

Figure 2. Representative results of ${ }^{99} \mathrm{Tc}$ assay with excess oxidant and heating. $\ldots \ldots \ldots \ldots 11$

Figure 3. Liquid scintillation beta spectra of Aliquat $336{ }^{99} \mathrm{Tc} \ldots \ldots \ldots \ldots \ldots \ldots \ldots$ 


\section{Executive Summary}

The nuclear fuels chemical reprocessing activities at Hanford went forward for many years with little attention about the presence or quantities of technetium in the systems. When needs changed, the analytical chemistry laboratories developed methods to isolate and measure technetium. It was found that if technetium could be oxidized, it could be readily and selectively extracted by organic based complexants. Over time, ever more efficient and lower cost methods were developed, mostly directed at aqueous solutions or simple sample matrices. With the change from production to waste cleanup, problematic sample matrices are causing unexpected discrepancies in the measurement of technetium.

This document traces the development of technetium analytical methods over the history of Hanford operations. The evolution of current issues and problems with the accepted analytical methods are described. Where possible and based on evidence, recommendations for improvements are described. A section on analytical directions is included which provides a rationale for the needed development and methodologies. Included are discussions about the effect of organic complexants in waste tank supernates or solutions and the observed problems with analyzing tank bottom sludges. 
HNF-5309, Rev 0. October 20, 1999

\section{Survey of Technetium Analytical Production Methods Supporting Hanford Nuclear Materials Processing}

\section{$1 \quad$ Introduction}

Interest in analytical measurement for technetium produced during the early chemical processing operations at Hanford was limited. No references to technetium analytical procedures for that period were identified during this study. However, by the mid 1950's there appeared to be a stronger interest in studying and recovering the by-products of the nuclear process as part of the Atoms for Peace program. References to technetium measurements were better documented. Hanford was involved in the recovery of technetium during that time and that work is summarized (Roberts, 1971). However, no Tc analytical methods were described in the document. The National Academy of Sciences Nuclear Science Series on The Radiochemistry of Technetium published in November 1960 summarizes several technetium analytical methods. Most of these focused on the separation of Tc from molybdenum. The methods in this NAS document for separation of $\mathrm{Tc}$ from the fission products used tetraphenylarsonium chloride to either precipitate or extract the technetium from other fission products. Distillation of Tc or precipitations were used to reduce interference from other beta emitting fission products. The predominant approaches then and now focus on the $\mathrm{Tc}(\mathrm{VII})$ or pertechnetate form of technetium as an isolatable species.

\section{Summary of Hanford Technetium Analytical Methods}

\subsection{Hanford Technetium Analytical Methods}

Six analytical methods have been identified as used to analyze technetium in Hanford chemical processing waste streams. There are five radiochemical separation methods and a method based on inductively coupled plasma mass spectrometry (ICP/MS). The radiochemical methods and their approximate chronological time of use are summarized in Table 1 A graph showing the correlation to nuclear fuel and waste reprocessing is shown in Figure 1

The first three methods were applied to either Purex waste streams or high level waste in the tanks. Because these methods were used during fuel processing periods, the short lived fission products $\left({ }^{95} \mathrm{ZrNb}\right.$, ${ }^{106} \mathrm{RuRh}$, and $\left.{ }^{144} \mathrm{CePr}\right)$ were much higher than today and the methods more subject to positive interferences if very clean separations of the Tc were not obtained. The Aliquat-336 method was directly aimed at analyzing Tc in waste containing organic complexants. The tetraphenylarsonium method was used by PNNL during the early 1990's as part of the tank waste characterization program. The use of ICP/MS for the determination of Tc in the waste did not start until about 1995. 


\begin{tabular}{|c|l|}
\hline \multicolumn{2}{|c|}{ Table 1. Hanford Radiochemical Technetium Methods } \\
\hline Date & \multicolumn{1}{c|}{ Basis of Method } \\
\hline 1963 & Extraction with Tri-Butylphosphate \\
\hline 1966 & Extraction with Cyclohexanone \\
\hline 1971 & Extraction with Tetrapropylammonium Hydroxide \\
\hline 1984 & Extraction with Aliquat-336 \\
\hline 1993 & $\begin{array}{l}\text { Extraction with Tetraphenylarsonium Chloride and } \\
\text { Hexone }\end{array}$ \\
\hline
\end{tabular}

\section{Hanford Chemical Processing \\ Technetium Analysis}

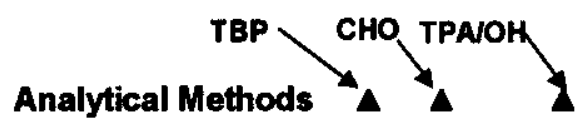

PUREX

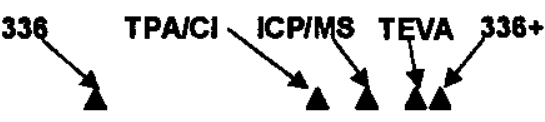

PUREX

\section{REDOX}

T-Plant

Tank Characterization

B-Plant (fuel)

B-Plant/WESF (Cs/Sr)

\section{0}

Figure 1. Hanford chemical processing relationship to technetium analytical method development. TBP = Tributylphosphate extraction, $\mathrm{CHO}=$ Cyclohexanone extraction, $\mathrm{TPA} / \mathrm{OH}=$ Tetraproplyammonium hydroxide extraction, $336=$ Aliquat 336 extraction, TPA/Cl $=$ Tetraphenylarsonium chloride extraction, ICP/MS = Inductively coupled plasma/mass spectrometer, TEVA $=$ Eichrom Industries filter (aliquat $336 \mathrm{~N}$ ), 336+ = Aliquat 336 extraction with heated peroxide step

\subsubsection{Tributyl Phosphate (TBP) Tc Method}


This TBP method (Campbell 1963) was developed in the early 1960's to determine Tc in PUREX waste streams and existing alkaline waste tank supernates. The sample was diluted into a final acid mixture with a concentration of $1 \mathrm{M} \mathrm{H}_{2} \mathrm{SO}_{4}$ and $0.025 \mathrm{M} \mathrm{NaF}$. One drop of concentrated $\mathrm{H}_{2} \mathrm{O}_{2}$ was added to oxidize the Tc to $\mathrm{Tc}(\mathrm{VII})$. After extracting the Tc into $45 \% \mathrm{TBP} / \mathrm{Soltrol}$ (kerosene mixture) the extracted Tc in the TBP was washed with the same acid mixture to remove residual fission products. The Tc was stripped from the TBP phase with water. Fission products and $\mathrm{U}$ and $\mathrm{Pu}$ isotopes in the water strip were removed by passing the aqueous phase through a Dowex 50X8 cation exchange resin. The effluent from the cation exchanger was collected on a beta mounting dish, dried and counted on a beta proportional detector.

This TBP method had reported Tc recoveries of about $92 \%$. The NaF was added to reduce the extraction of ${ }^{95} \mathrm{ZrNb}$. Decontamination factors of about $10^{4}$ were obtained for ${ }^{95} \mathrm{ZrNb}$ and ${ }^{106} \mathrm{RuRh}$. This method did not use tracers or spikes to correct for the extraction efficiency. Later reports indicated that the $92 \%$ recovery yield could not always be achieved.

\subsubsection{Cyclohexanone Tc Method}

The Tc cyclohexanone method (Campbell 1966) was also applied to Purex waste streams. One of the method's primary advantages was the ability to dilute the cyclohexanone directly into a liquid scintillation cocktail for counting. This eliminated the drying step required for beta proportional counting and also the possibility of $\mathrm{Tc}$ losses during drying.

The method extracts Tc from a $0.5 \mathrm{M} \mathrm{H}_{3} \mathrm{PO}_{4}$ matrix. Phosphoric acid was found to provide the best decontamination from ${ }^{106} \mathrm{RuRh}$ and the best de-entrainment from the cyclohexanone. The potential for ${ }^{106} \mathrm{RuRh}$ contamination could still be a problem if the sample size was too large. Small amounts of ${ }^{106} \mathrm{RuRh}$ contamination could be corrected for by the liquid scintillation counting procedure. Hydrogen peroxide was used to oxidize $\mathrm{Tc}$ to $\mathrm{Tc}$ (VII). The $\mathrm{Tc}$ recovery for spikes with this procedure was $97.7 \%$. The decontamination factor for ${ }^{106} \mathrm{RuRh}$ was about $10^{3}$. Even though this method was faster it does not appear to have as good as fission product decontamination factors as the TBP method.

\subsubsection{Tetrapropylammonium Hydroxide (TPAOH) Tc Method}

The tetrapropylammonium hydroxide Tc method was developed for the analysis of Purex acid waste solutions (Smith 1974). The method was tested on waste from the AX tank farm and the current acid waste (CAW) from Purex. It does not appear that this method was used extensively for any routine operations but was developed for a specific project that did not materialize. The $\mathrm{Tc}$ is oxidized to $\mathrm{Tc}$ (VII) with hydrogen peroxide. Diethylenetriaminepentaacetic acid (DTPA) is added to complex other metals or extractable radionuclides. The extraction of the Tc-TPAOH complex is made from about $3 \mathrm{M} \mathrm{NaOH}$ with a 50:50 mixture of chloroform and methylisobutlyketone. Decontamination from fission products is about $10^{5}$ with the exception of a small amount of ${ }^{110 \mathrm{~m}} \mathrm{Ag}$ which extracted from CAW. The spike recovery for the method was 
$102.9 \pm 5.9 \%$. The beta count was corrected by using gamma energy analysis of the mount for other beta emitting isotopes; these were normally small or non-existent.

\subsubsection{Aliquat-336 Tc Method}

The Aliquat-336 method (Metcalf 1984) has been the predominant Tc method used by the 222-S Laboratory since its development in 1984. The quaternary amine, Aliquat-336, essentially behaves as a liquid anion exchanger. The sample is diluted in $4 \underline{\mathrm{M}} \mathrm{HNO}_{3}$ and the Tc oxidized to $\mathrm{Tc}$ (VII) with $\mathrm{H}_{2} \mathrm{O}_{2}$ and heat. As discussed later in this report, sometime in the historical use of this procedure the heating of the peroxide step was dropped from the procedure. This omission created problems in samples with high organic complexant content because of the incomplete oxidation of the Tc in these matrices. After oxidation, Tc is extracted into $30 \%$ Aliquat$336 / x y l e n e$ using two contacts. The organic phase is removed and washed once with $4 \underline{\mathrm{M}} \mathrm{HNO}_{3}$ and once with $4 \mathrm{M} \mathrm{NaOH}$. The present method has been modified from the original study and a final $4 \mathrm{M} \mathrm{HNO}_{3}$ wash performed on the organic before transferring an aliquot to the liquid scintillation vial. This wash and a few drops of glacial acetic acid were added to reduce fluorescence of the Aliquat-336 in the scintillation vial.

The average spike recovery on waste from AY-101, AZ-102, AW-104 and AW-105 in the original study was $92.5 \pm 4.8 \%$. All the results from this method are corrected for the spike recovery. Therefore, the results are sensitive to the reproducibility of the technologist. Standard recoveries for the method are typically $102.9 \pm 7.5 \%$ at the $95 \%$ confidence level.

\subsubsection{Tetraphenylarsonium Tc Method}

The tetraphenylarsonium method is used by the PNNL laboratories to determine Tc in Hanford tank waste. Originally the method used dichromate to oxidize the Tc to Tc(VII). However, because of the oxidation problems identified in the high organic complexant waste, the oxidizing agent has been changed in 1997 to ceric ion and the oxidizing conditions made more rigorous. After the oxidation step the sample is passed through a cation exchange resin to remove other potential beta emitting isotopes. Tetraphenylarsonium chloride is then added to complex the pertechnetate anion in the ion exchange effluent. The technetium tetraphenylarsonium complex is extracted into hexone and an aliquot of the hexone dried and counted by a beta gas flow proportional counter to determine the technetium concentration. The results from this method are not normally corrected for spike recovery through the system utilizing a second aliquot of sample. However, PNNL laboratories have occasionally utilized ${ }^{99 \mathrm{~m}} \mathrm{Tc}$ as a tracer and corrected the results based on the tracer recovery.

\subsubsection{TEVA Resin Method for Tc}

In recent time, innovative extraction media have become available for use in separating ${ }^{99} \mathrm{Tc}$. As an example, Eichrome Industries perfected a technetium specific anionic resin for extracting low 
levels of Tc from environmental waters. The TEVA ${ }^{1}$ filter is a polyacrylic filter bed impregnated with a non-mobile form of Aliquat-336. As with other methods using the extractant, the technetium must be maintained at the $\mathrm{Tc}$ (VII) level for extraction to occur. Although clever in principle, application to directly prepared tank waste samples shows interference from ${ }^{137} \mathrm{Cs}$. The problem arises from the relatively enormous concentration of ${ }^{137} \mathrm{Cs}$ over ${ }^{99} \mathrm{Tc}$. Sample liquid is entrained in the filter clamp region of the filtration apparatus. Not all of the ${ }^{137} \mathrm{Cs}$ can be washed out and activity sufficient to overshadow the ${ }^{99} \mathrm{Tc}$ will remain for the counting step. Therefore, this method, although perfected for environmental samples, is not in use for tank samples. The TEVA exchange material may also be used in a column to separate Tc. However, the method has not been evaluated for high level waste at Hanford.

\subsubsection{ICP/MS Method for Tc}

The ICP/MS method used at Hanford does not utilize a chemical separation of Tc from the waste matrix. The sample is either 1) diluted in acid if liquid, 2) digested in $\mathrm{HNO}_{3} / \mathrm{H}_{2} \mathrm{O}_{2} / \mathrm{HCl}$ as per EPA SW-846 method $3050^{2}$ or 3) fused in $\mathrm{KOH}$ and dissolved in $\mathrm{HCl}$. Because the mass spectrometer is more isotope selective than beta counting, the method is subject to fewer interferences. Isobaric interferences are possible from Ru. However, Ru has other isotopes that may be checked to determine if it is present in significant quantities. Ruthenium has not been a problem in samples examined to this date and the DOE Savannah River Plant has had similar experiences. The prepared waste samples are normally diluted by a factor of $10^{3}$ to $10^{4}$ to reduce the dissolved solids content of the samples. Larger dilutions are required for the $\mathrm{KOH}$ fusion preparations and this may lead to detection limit problems for some samples. The ICP/MS method is simpler than the radiochemical method because separations are not normally required. Therefore it is 1) faster and 2) less prone to technician errors and 3) less likely to have Tc losses. There have been instances for some sludge samples where the ICP/MS data suggest that the present acid digestion may not be as complete as the $\mathrm{KOH}$ fusion. Further comparisons between acid and fusion sample preparations are needed to confirm these observations. The ability to confirm the analysis for Tc by a second independent technique provides a high level of confidence in the data. Therefore, continued characterization of waste and comparison of the results using both ICP/MS and radiochemistry is recommended.

\section{$2.2 \quad$ Speciation of Technetium}

All of the present radiochemical methods are designed with oxidation steps to convert other $\mathrm{Tc}$ valence states to pertechnetate and provide total Tc results for the samples. If the procedures

${ }^{1}$ TEVA is a trademark of Eichrome Industries.

${ }^{2}$ It is acknowledged that use of $\mathrm{HCl}$ is not strictly specified. This acid can conflict with the accepted use of ICP/MS. Other similar methods such as EPA method 200.8 include $\mathrm{HCl}$ and this acid is required for proper dissolution of Hanford high iron content tank samples. 
were modified to eliminate the oxidation steps then the separations would reflect the concentration of pertechnetate, $\mathrm{Tc}$ (VII), in the samples. The affect of any sample preparation on the Tc valence must also be considered in the evaluation of the Tc species. For alkaline supernates, the acidification of the sample for extraction could result in valence changes and therefore not reflect the Tc valence in the actual tank wastes. For solid samples, analysis of water leaches may provide the best estimate of Tc(VII). Because the tetrapropylammonium hydroxide Tc separation is performed from an alkaline medium, it may be the preferred approach for Tc speciation with less chance of the method conditions changing the Tc valence. Evaluating the Tc speciation in waste with high concentrations of organic complexants becomes more difficult because anionic complexes of lower Tc valence states may be present. Because of the complex chemistry of the Hanford waste, additional testing and evaluation is recommended to assure accurate Tc speciation data is obtained.

\section{Technetium Analyses for Sample Exchange and Evaluation (SEE) Program}

In 1993, a sample exchange program was established between the 222-S laboratory in the 200-W processing area operated by Westinghouse Hanford Company and the 325 Laboratory in the 300 area operated by Pacific Northwest National Laboratory (PNNL). The objective of the SEE program was to compare and evaluate the different methods used to characterize the waste in Hanford's single shell and double shell tanks.

The program was carried out in several phases from 1993 to 1997 . Initially the program focused on radionuclide analyses because of the different separation and measurement schemes used by the laboratories and because no nationally accepted standard radiochemical methods are available. As the program progressed, the sample preparation complexity increased from handling homogeneous liquids to homogenized solids with different dissolutions. Discussions here relate to solid samples as prepared by either $\mathrm{KOH}$ fusion or acid digest. Technetium was one of the analytes that was compared in the SEE program. Therefore, the SEE data can provide further insight into the reproducibility of these methods and associated potential problems.

\subsection{SEE Technetium Methods}

The 222-S and 325 laboratory ${ }^{99} \mathrm{Tc}$ methods used in this program were based on radiochemistry but used different oxidation, separation and counting technologies. Inductively coupled plasma mass spectrometry (ICP/MS) was available at the 325 laboratory and was run along with the radiochemical analyses on several occasions.

The 222-S method was essentially the same as the radiochemical method described in section 2.1.4 (Metcalf 1984). The Tc is normally analyzed on a $\mathrm{KOH}$ fused waste sample that is dissolved in hydrochloric acid $(\mathrm{HCl})$. An aliquot of the fused sample is adjusted to about $4 \mathrm{M}$ $\mathrm{HNO}_{3}$ and the Tc oxidized to Tc (VII) with hydrogen peroxide. Recently a heating step was added to this oxidation to ensure that $\mathrm{Tc}$ is oxidized in the presence of organic complexants. 
However, this was not done during the SEE program. The Tc (VII) is then extracted into Aliquat-336, a quaternary amine liquid anion exchanger. The Aliquat-336 is washed with $4 \underline{\mathrm{M}}$ $\mathrm{HNO}_{3}$ and $\mathrm{NaOH}$ to remove other beta emitting interferences. A aliquot of the Aliquat-336 is finally diluted into a liquid scintillation cocktail and counted. A second sample aliquot is spiked with a known amount of Tc-99 and carried through the same procedure. The final result is corrected for the chemical yield of the Tc-99 spike.

The 325 laboratory uses a similar $\mathrm{KOH}$ fusion and dissolution method as the 222-S lab. Technetium is oxidized to $\mathrm{Tc}(\mathrm{VII})$ using dichromate before removing potential beta emitting interferences via a cation ion exchange column. The Tc in the effluent is further purified by complexing it with tetraphenylarsenate and extracting the complex into hexone. An aliquot of the hexone is mounted in a 1 " counting dish and counted on a gas flow proportional counter. The 325 laboratory results were not corrected for chemical yield based on a spike. Instead, ${ }^{99 \mathrm{~m}} \mathrm{Tc}$ is used as a tracer to correct for chemical yield. The ${ }^{99 \mathrm{~m}} \mathrm{Tc}$ tracer was not normally used in the SEE program.

\subsection{SEE Phase I Technetium Results}

The Tc-99 analyses in Phase I were performed on solid samples from tanks B-111 and T-107. The samples were all prepared by $\mathrm{KOH}$ fusion at the 325 laboratory and the dissolutions split for analysis at the two laboratories. In addition to the tank materials, QC standards for Tc were also analyzed. The results of these analyses are summarized in Table 2.

\begin{tabular}{|c|c|c|c|}
\hline \multirow{2}{*}{ Tank/Standard } & \multirow{2}{*}{$\begin{array}{l}\text { Average RPD - \% } \\
\text { (325-222S)/Average }\end{array}$} & \multicolumn{2}{|c|}{ Percent Recovery for Standards } \\
\hline & & 325 & 222-S \\
\hline B-111 & 11.4 & & \\
\hline $\mathrm{T}-107$ & -19.3 & & \\
\hline 325 Lab Standard & -2.0 & 110.3 & 112.5 \\
\hline 222-S Lab Standard & 19.1 & 78.7 & 95.4 \\
\hline
\end{tabular}

For the eight B-111 waste aliquots analyzed, the average relative percent difference (RPD) between the two laboratories was $11.4 \%$. The 325 lab was higher in 7 of the 8 analyses for this tank. The average RPD between the labs for the four samples from tank T-107 waste was $19.3 \%$ with the 222-S lab having the highest value for all the samples. The 222-S lab utilized smaller samples which tended to increase counting errors. 
HNF-5309, Rev 0. October 20, 1999

\subsection{SEE Phase II Technetium Results}

Technetium was determined on waste from tanks B-201 and C-112 in Phase II of the SEE program. The Tc results on B-201 were too low for comparison. The RPD between the two lab Tc results for C-112 was $16.3 \%$ with the $222-\mathrm{S}$ laboratory being higher. The average $222-\mathrm{S}$ standard recovery was $100.9 \%$. The 325 lab standard recovery was $84.6 \%$ with a RPD between labs of $17.6 \%$ similar to the RPD for $\mathrm{C}-112$ samples. The estimated counting error for the analyses was about $10 \%$ for both laboratories. The ICP/MS technetium result on an acid digestion $(\mathrm{HNO} / \mathrm{H} 2 \mathrm{O} 2 / \mathrm{HCl}$ ) of the $\mathrm{C}-112$ was 100 times less than the radiochemical analysis of the sample prepared by fusion. This could be an indication of a positive interference in the radiochemical method or possibly a difference in the effectiveness of the digestion procedures. A negative ICP/MS interference or a homogeneity difference of this magnitude seems less likely.

\subsection{SEE Phase III Technetium Results}

A homogenized sample of B-204 waste was split between the two laboratories and analyzed for Tc in Phase III. The 222-S lab reported a $<0.035 \mu \mathrm{Ci} / \mathrm{g}$ and the 325 lab reported $0.028 \mu \mathrm{Ci} / \mathrm{g}$. The results are consistent but are not comparable. Some problems were encountered with the Tc standards data. After the 222-S lab re-analyzed the standards, the results were about $19 \%$ higher than the 325 laboratory.

\subsection{SEE Phase IV and V Technetium Results}

No technetium analyses were performed in Phase IV of the program. In Phase V, Tc-99 analyses were performed on $\mathrm{AW}-101$ and $\mathrm{AN}-107$ double shell supernate wastes. The $\mathrm{AW}-101$ supernate waste is low in organic complexants; whereas, the $\mathrm{AN}-107$ waste has high organic complexant concentrations. The results for both labs were the same (RPD $=0.0 \%$ ) for the AW-101 samples. The RPD between the radiochemical and ICP/MS results on AW-101 was $18.8 \%$ with the radiochemical result being the higher. The Tc results for the AN-107 sample are summarized in Table 2.

\begin{tabular}{|c|c|c|c|c|}
\hline \multicolumn{5}{|c|}{ Table 3. Technetium Results for Tank AN-107 Supernate } \\
\hline $\begin{array}{c}\text { 222-S Radchem } \\
\boldsymbol{\mu C i} / \mathbf{m L}\end{array}$ & $\begin{array}{c}\text { RPD -\% } \\
(325-222 S) / A v\end{array}$ & $\begin{array}{c}\text { Radchem 325 } \\
\boldsymbol{\mu C i} / \mathrm{mL}\end{array}$ & $\begin{array}{c}\text { RPD - \% } \\
(\text { Rad-ICP)/Av }\end{array}$ & $\begin{array}{c}\text { 325 ICP/MS } \\
\boldsymbol{\mu C i} / \mathrm{mL}\end{array}$ \\
\hline 0.052 & 65.0 & 0.10 & 22.6 & 0.13 \\
\hline
\end{tabular}

The 325 Laboratory changed to a more vigorous oxidation procedure using ceric ion and heat in their radiochemical method for this high complexant matrix. This improved the conversion of Tc species to $\mathrm{Tc}$ (VII) and produced results similar to the ICP/MS. The 222-S lab was using the $\mathrm{H}_{2} \mathrm{O}_{2}$ oxidation without heat which fails to oxidize all the $\mathrm{Tc}$ to $\mathrm{Tc}(\mathrm{VII})$. As discussed in the 
method section of this report, this oxidation step has been modified to include heat which has been shown to give comparable results with ICP/MS on high complexant waste samples.

\subsection{SEE Program Conclusion}

The SEE program data indicates that in most cases the radiochemical data between the labs are comparable (RPD $<20 \%$ ). The 222-S lab appears to produce higher radiochemical results than the 325 lab. This could be a result of applying the spike recovery correction factor to the data. The SEE program data shows the need for stronger oxidation conditions when analyzing high complexant waste. The independent ICP/MS technology is valuable for identifying potential problems in radiochemical analyses and in dissolution procedures as indicated in the C-112 results for acid and fusion prepared samples. Unfortunately the SEE data set is still relatively small to adequately explain some of the observed differences and make conclusive statements.

\section{Current Findings}

\subsection{Evolution of Issues}

The 222-S Laboratory (222-S) at Hanford provides significant analytical support in the characterization of defense nuclear waste identified above. It was shown (Schroeder, 1995) that certain laboratory measurements did not provide complete measurement of the ${ }^{99} \mathrm{Tc}$ concentration in tank samples. In particular, aqueous liquid supernates from tanks with large quantities of organic complexants showed losses in excess of 50\%. Evidence of these losses is shown in Table 4 from rigorous analysis at Los Alamos National Laboratory (LANL) (Schroeder, 1995) as compared to routine analysis results from 222-S Laboratory.

Table 4. [ $\left.{ }^{99} \mathrm{Tc}\right]$ Analysis Comparison for Organic Complex Supernate Samples

\begin{tabular}{|c|c|c|c|}
\hline Sample & LANL $^{*}$ & 222-S* & Ratio, LANL/222-S \\
\hline SY-101 & $5.9 \mathrm{E}-05$ & $1.7 \mathrm{E}-05$ & 3.5 \\
\hline SY-103 & $6.6 \mathrm{E}-05$ & $3.5 \mathrm{E}-05$ & 1.8 \\
\hline *Values as Molar concentration
\end{tabular}

These data and the associated evaluation created a need to investigate the performance of the primary ${ }^{99}$ Tc procedure at 222-S. Correspondingly, Pacific Northwest National Laboratory (PNNL) made several reagent studies on the separation of ${ }^{99} \mathrm{Tc}$ using modifications of the LANL and PNNL procedures (Fadeff, 1996). These studies showed that the organic complexants are of concern in the ${ }^{99} \mathrm{Tc}$ measurement and that proper ${ }^{99} \mathrm{Tc}$ can be recovered if the organics are 
properly processed. Investigation into this and further issues on aged sludges are summarized here.

\subsection{Effects of Aged Organic Wastes}

As tank characterization sampling moved to tanks with significant quantities of organics, the complex nature of ${ }^{99} \mathrm{Tc}$ chemistry and complexes was observed. As noted in section 3.1, the radchem method at 222-S generated results considerably lower than more rigorous oxidation methods and ICP/MS. This led to investigation of the 222-S method. The original work utilizing tricapryl methyl ammonium chloride (Aliquat-336) (Metcalf, 1984), on simulated organic complexes showed no effect from heating the sample during the oxidation step. Thus, the formal implementation omitted the heating step. It was found that the heating step is crucial in assuring that all entrained ${ }^{99} \mathrm{Tc}$ is released and/or oxidized to $\mathrm{Tc}$ (VII) for anionic removal by Aliquat-336 (Troyer, 1998). Evidence is presented in Table 5 in which a non-organic tank (AN-105) is compared to organic tanks (AN-107 and SY-101). Further evidence is shown in Figure 2 in which several combinations of oxidant and temperature levels were used with the Aliquat-336 extraction. A fallout of this work is that some speciation inference may be possible with proper use of the heat step. The base method at 222-S was modified to include the heating step in 1998 (Relyea, 1998).

\begin{tabular}{|c|c|c|c|c|}
\hline \multicolumn{5}{|c|}{ Table 5. Results of Tank Supernate Sample Comparisons - ${ }^{99} \mathrm{Tc} \mu \mathrm{Ci} / \mathrm{L}$} \\
\hline Tank Sample & $\begin{array}{c}\text { Total Organic } \\
\text { Carbon, g/L }\end{array}$ & $\begin{array}{c}\text { 222-S } \\
\text { No Heat }\end{array}$ & $\begin{array}{c}\text { 222-S } \\
\text { With Heat }\end{array}$ & ICP/MS \\
\hline AN-105 & - & 244 & - & 255 \\
\hline AN107 & 60 & 53.2 & 106 & 101 \\
\hline SY-101 & 15 & 288 & 604 & 634 \\
\hline
\end{tabular}

\subsection{Tank Sludges and Solids}

\subsubsection{AX-104 Sludge Heel}

Samples were taken from the emptied tank AX-104 in support of Hanford Tank Initiative (HTI) for risk assessment of residual materials. The primary focus was the water leach rate of various components from the waste (Crawford, 1998a, 1998b). Technetium was a primary component of interest. 
Blended samples from two tank riser access locations were analyzed for ${ }^{99} \mathrm{Tc}$ by ICP/MS, Laser Ablation Mass Spectrometry (LAMS), and radiochemical separation. Significant differences and poor replication were found among the data for core riser $9 \mathrm{G}$ as summarized in Table 6 . It should be noted that results for individual $9 \mathrm{G}$ and $3 \mathrm{~A}$ samples were from acid digest preparations. The 9G composite Tc samples were prepared by $\mathrm{KOH}$ fusion. Further work on AX-104 is dependent

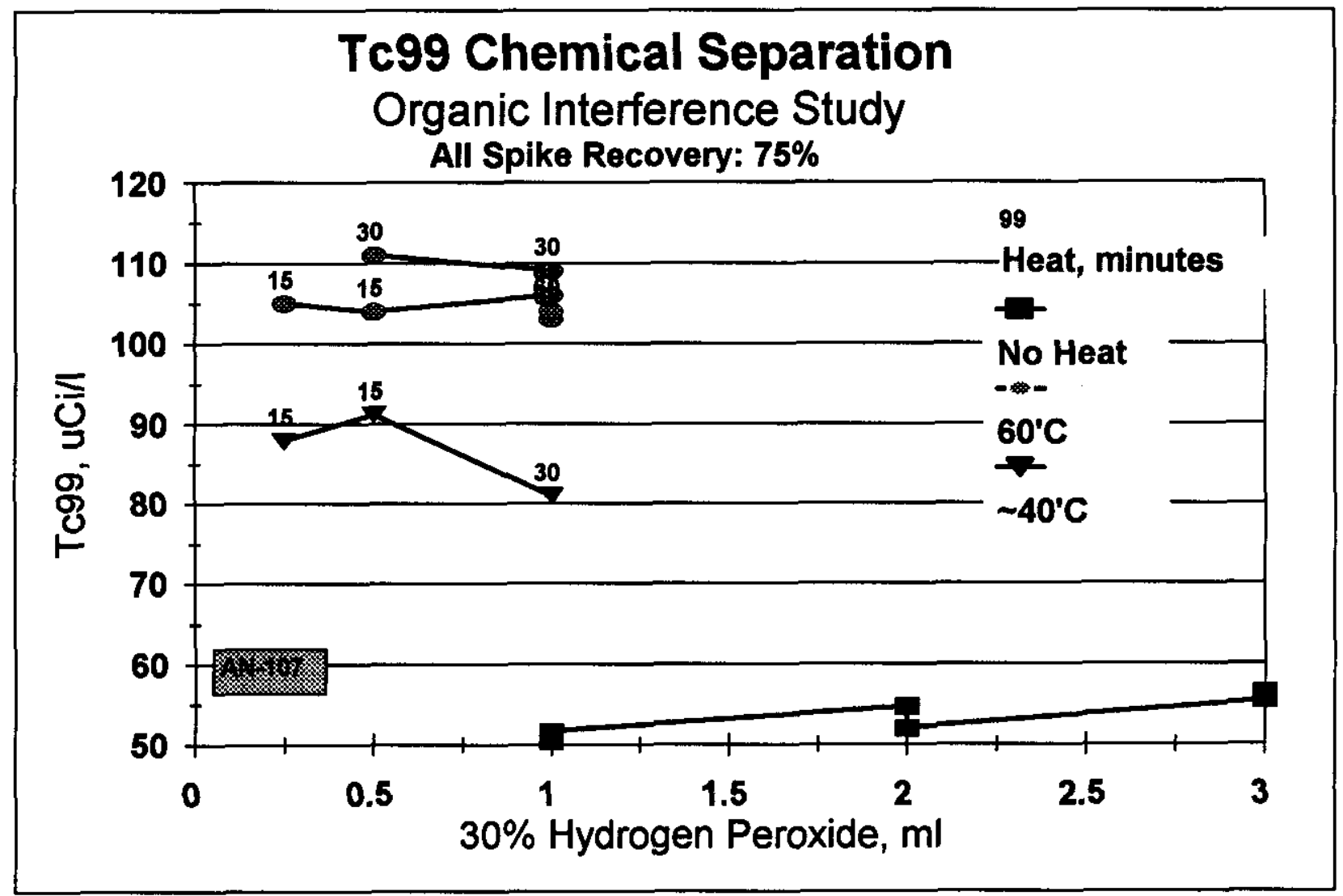

Figure 2. Representative results of ${ }^{99} \mathrm{Tc}$ assay with excess oxidant and heating. Note that excess oxidant has insignificant impact on releasing or oxidizing the Tc to a species suitable for Aliquat-336 extraction.

on acquiring additional sample material. 
HNF-5309, Rev 0、October 20, 1999

\begin{tabular}{|c|c|c|c|c|c|c|}
\hline \multicolumn{7}{|c|}{ Table 6. Tank AX-104 Sludge 99 Tc Results } \\
\hline Source Riser & $\begin{array}{c}\text { ICP/MS } \\
\mu \mathrm{Ci} / \mathrm{gm}\end{array}$ & \%RPD & $\begin{array}{c}\text { LAMS } \\
\mu \mathrm{Ci} / \mathrm{gm}\end{array}$ & $\%$ RPD & $\begin{array}{c}\text { RadChem } \\
\mu \mathrm{Ci} / \mathrm{gm}\end{array}$ & \%RPD \\
\hline 9G & $<.02$ & N/A & $<.02$ & N/A & .8 to 3.0 & $<100 \%$ \\
\hline $3 \mathrm{~A}$ & $<.0002$ & N/A & $<.02$ & N/A & $<.02$ & N/A \\
\hline 9G Composite & .65 & No Duplicate & & & .4 & $47 \%$ \\
\hline
\end{tabular}

\subsubsection{C-104 Sludge}

During FY1998, samples of Hanford high level waste tank 241-C-104 bottom sludge were analyzed for performance assessment of leaching and various component content. Initial radiochemistry (radchem) results were higher than expected and became important concerns regarding ${ }^{99} \mathrm{Tc}$ concentrations for decision criteria on retrieval/pre-treatment process flowsheets. Due to previous studies (Crawford, 1998a/b; Troyer, 1998), the opportunity to further assess the reliability between radchem and Inductively Coupled/Mass Spectrometry (ICP/MS) was exploited. As shown in Table 7, the initial analyses for C-104 showed that the ICP/MS produced results 50 times lower than the radchem, a direct inversion of previous experience with organic complexant waste (Troyer, 1998). This evidence initiated a study to resolve the difference.

\begin{tabular}{|c|c|c|}
\hline Method & $\mu \mathrm{g} / \mathrm{g}$ & $\mu \mathrm{Ci} / \mathrm{g}$ \\
\hline${ }^{99} \mathrm{Tc}$ by ICP/MS LA-505-159 & 2.05 & $(.035)$ \\
\hline${ }^{99}$ Tc by Liq. Scint & (99) & 1.7 \\
\hline
\end{tabular}

A test plan was developed to resolve the ${ }^{99} \mathrm{Tc}$ differences. A series of new sample preparations were defined: water leach, acid digest, and $\mathrm{KOH}$ fusion. The water leach was expected to provide inference as to the soluble pertechnetate ( $\mathrm{Tc}(\mathrm{VII})$ ) species. Duplicate aliquots were digested and submitted for ICP/MS and radchem analysis. A secondary, no-heat/oxidation step variation was also prescribed for further potential speciation. For the digest and fusions, a predigest spike with ${ }^{99} \mathrm{Tc}$ standard was also included All of these aliquots were submitted for both ICP/MS and radchem. 
The results of these tests essentially confirmed the initial results. The ICP/MS showed considerably lower results than the radchem. However, a significant instability also appeared in the radchem results. The primary indicator was loss of control of the internal analytical quality control. Several attempts were made to improve the results through analytical reruns. A summary of the data is shown in Table 8.

As shown in Table 8, the ICP/MS results were consistently lower than the radchem, in initial cases, by as much as 50 to 150 times. It is also shown that the radchem reported generally unstable results with an indication of downward trend over time. The less than detectable measurement by ICP/MS for the fusion is a factor of diluting the excess salts generated by the fusion process for proper operation in this instrument.

Several attempts were made to resolve the continuing discrepancy. The acid digest prepared stocks were conditioned with additional hydrogen peroxide and heat. Aliquots of these were again submitted to ICP/MS and radchem. The results are shown in Table 13 as the oxidation strike data row. As before, the ICP/MS showed consistent results while the radchem shows continued instability as reflected in the relative per cent difference (RPD) value.

\begin{tabular}{|c|c|c|c|c|c|c|}
\hline \multicolumn{7}{|c|}{ Table 8. Tank C-104 Sludge 222-S ${ }^{99}$ Tc Reanalysis* } \\
\hline \multirow[b]{2}{*}{ Preparation } & \multicolumn{3}{|c|}{$\mathrm{ICP} / \mathrm{MS}, \mu \mathrm{Ci} / \mathrm{gm}$} & \multicolumn{3}{|c|}{ Radchem, $\mu \mathrm{Ci} / \mathrm{gm}$} \\
\hline & Sample & Duplicate & RPD & Sample & Duplicate & RPD \\
\hline \multirow[t]{5}{*}{ Caustic Fusion } & $<0.043$ & & & 3.2 & 3.0 & 6 \\
\hline & & & & 1.9 & 2.1 & 8 \\
\hline & & & & 0.15 & 0.25 & 50 \\
\hline & & & & 0.16 & 0.32 & 65 \\
\hline & & & & 0.54 & 1.30 & 82 \\
\hline \multirow[t]{3}{*}{ Acid Digest } & 0.016 & 0.014 & 13 & 2.9 & 11.00 & 117 \\
\hline & & & & 2.0 & 1.8 & 12 \\
\hline & & & & 0.21 & 0.22 & 7 \\
\hline $\begin{array}{c}\text { Acid Digest } \\
\text { w/oxidation strike }\end{array}$ & .022 & .018 & 20 & 1.36 & 0.31 & 125 \\
\hline Water Leach & 0.0079 & .0079 & 1 & 0.02 & 0.03 & 24 \\
\hline
\end{tabular}

Examination of the liquid scintillation spectra for this last set of radchem analyses showed that a significant contaminant was present. Further investigation with pure nuclide standards showed that the liquid scintillation spectra for ${ }^{241} \mathrm{Pu}$ are quite similar to the sample spectrum. Comparison of sample, sample+spike (tracer), and ${ }^{99} \mathrm{Tc}$ standard spectra (Figure 3.) indicate such a contaminant. Commonly, the ${ }^{99} \mathrm{Tc}$ liquid scintillation results are created by integrating an energy 
region of interest from zero to the ${ }^{99} \mathrm{Tc}$ energy endpoint. As evidenced in the spectra in Figure 3., this includes the significant low energy response from the suspect ${ }^{241} \mathrm{Pu}$. No other beta/gamma emitting nuclides were detected with gamma assay ${ }^{3}$ of the separated materials. The mechanism for carryover of plutonium into the extractant is unknown. The discovery is likely due to a higher partitioning of plutonium into the sludges due to caustic matrix solubilities. To date, a minor concentration of plutonium in supernates has not been a significant confounding contaminant in the extraction procedure.

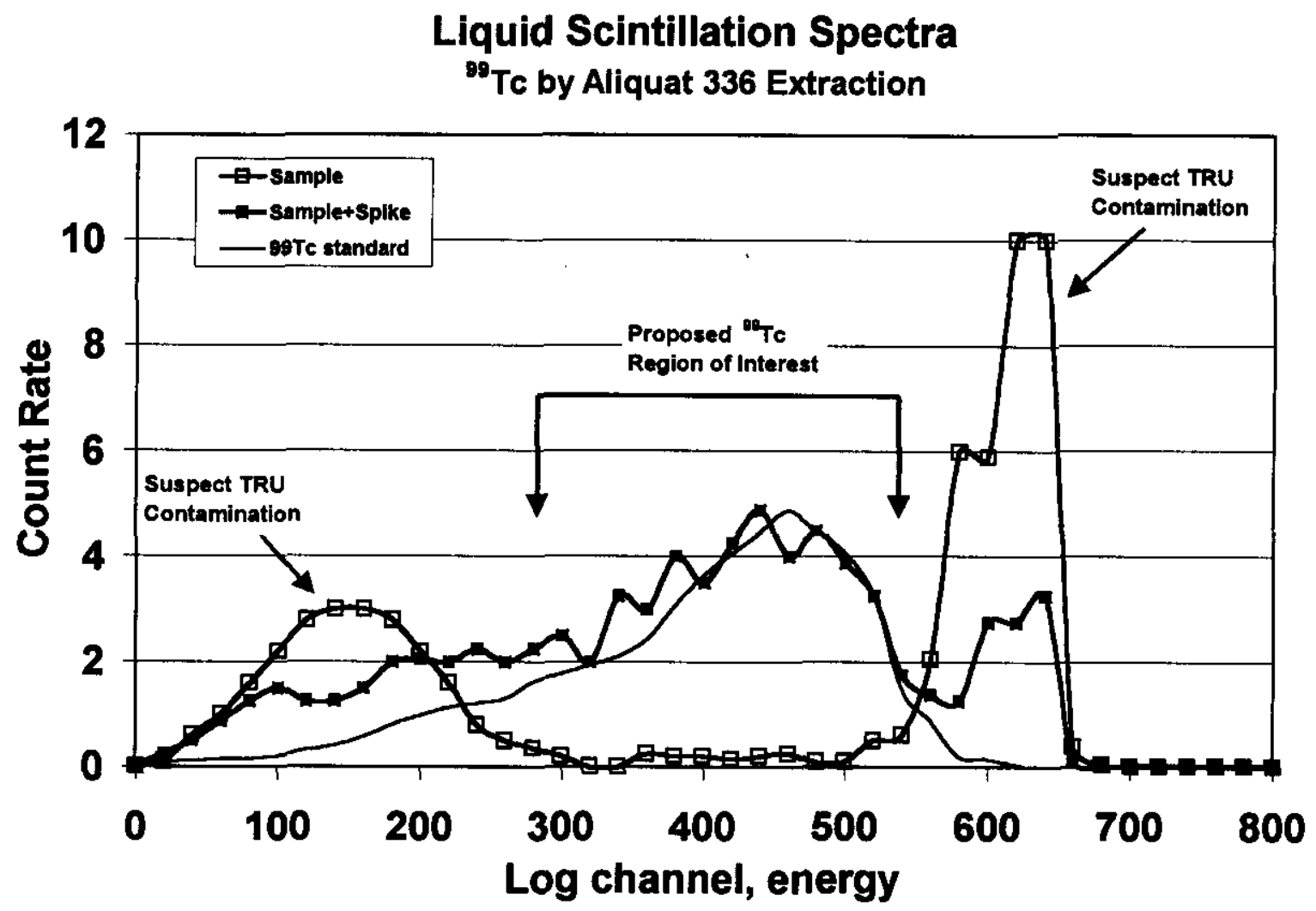

Figure 3. Liquid scintillation beta spectra of Aliquat $336{ }^{99} \mathrm{Tc}$ extraction from prepared C-104 sludge sample material. Spectra for sample and "sample+spike" are adjusted for dilution, ${ }^{99} \mathrm{Tc}$ standard is normalized to "sample+spike". Region of interest provides response of sample/spike ratio comparable to ICP/MS.

Based on these studies, it is evident that more information on the chemistry of aged nuclear waste sludges is needed. An immediate work around establishing a specific spectral region of interest for ${ }^{99} \mathrm{Tc}$ in the liquid scintillation counting is recommended. A proposed region of interest efficiencies.

${ }^{3}$ Confirmation of ${ }^{241} \mathrm{Pu}$ by ${ }^{241} \mathrm{Am}$ gamma assay is not likely due to liquid scintillation/HPGe detector relative 
integration as shown in Figure 3. provides ratios between the sample and sample+spike comparable to the ratios found by ICP/MS. In addition, routine examination of the beta spectra is needed to assure that other contaminants are avoided. Finally, further investigations into improvements in decontamination and stability of the radchem method are needed.

\subsubsection{Tank C-106 Slurry}

During 1996, twenty grab samples were taken from the slurry portion of Tank C-106. These samples were used by PNNL to estimate effects of sludge washing and preparation for feed to vitrification processes. These samples underwent significant dilution, compositing, splitting, and washing operations. From these operations, two primary sample types are identifiable for ${ }^{99} \mathrm{Tc}$ comparisons (Esch, 1997). A summary of the ${ }^{99} \mathrm{Tc}$ results is shown in Table 9, all data generated by ICP/MS. The first is an Original Material (OM). This comprised a composite of all the samples and diluted by a ratio of $3: 2$ with water. Three aliquots of the OM were dried and protions processed by both acid digest and $\mathrm{KOH}$ fusion.

The second material was a Vendor Product (VP) developed by repeated washing of the OM with various caustic solutions. Resulting solids were separated by centrifugation and decanting. These solids were then dried and subjected to various tests.

Table 9. ${ }^{99}$ Tc Analysis Summary of Envelope D Sampling of Tank C-106

\begin{tabular}{|l|c|c|}
\hline \multicolumn{1}{|c|}{ Sample Material } & $\begin{array}{c}\text { KOH Fusion, } \\
\mu \mathrm{Ci} / \mathrm{gm}\end{array}$ & $\begin{array}{c}\text { Acid Digest, } \\
\mu \mathrm{Ci} / \mathrm{gm}\end{array}$ \\
\hline Original Material, composited and dried. & $9.6 \mathrm{E}-2$ & $3.1 \mathrm{E}-2$ \\
\hline Vendor Product, washed and dried solids. & N/A & $5.7 \mathrm{E}-3$ \\
\hline
\end{tabular}

As has been generally noted, the ICP/MS results check internally quite well (Esch, 1997). Therefore the difference observable between the $\mathrm{KOH}$ and acid preparation are not suspect. It was noted that blending of samples produced magnetic particles on the stir bars and that these were included in the acid digest. No further comments on the condition of the digested samples were found. Finally, the results from the VP samples imply that a significant portion of the ${ }^{99} \mathrm{Tc}$ is in an unincorporated form, likely the pertechnetate species, as only about $10 \%$ remained in the VP.

\subsubsection{Additional Sludge Washing Performance}

The partitioning of tank waste materials continues to be evaluated through caustic washing and leaching. A recent report (Lumetta, 1998) identifies a number of tank materials processed similar 
to the C-106 efforts (Esch, 1997). Prepared samples, washes, and residual solids were assayed for several components of interest including ${ }^{99} \mathrm{Tc}$. Based on these results as shown in Table 10, a signifcant amount of the ${ }^{99} \mathrm{Tc}$ is soluble and can be removed from the solids by simple washing. All results were generated by ICP/MS.

\begin{tabular}{|c|c|c|c|c|c|c|c|c|}
\hline \multirow[b]{2}{*}{$\begin{array}{l}\text { Tank } \\
\text { Sample }\end{array}$} & \multicolumn{4}{|c|}{$0.1 \mathrm{M} \mathrm{NaOH}$ Wash } & \multicolumn{4}{|c|}{ Solids Washing } \\
\hline & $\begin{array}{c}\text { Original } \\
\text { Sample } \\
\mathrm{uCi}\end{array}$ & $\begin{array}{c}\text { Combined } \\
\text { Wash } \\
\text { uCi }\end{array}$ & $\begin{array}{l}\text { Washed } \\
\text { Solids } \\
\text { uCi }\end{array}$ & $\begin{array}{l}\% \text { Decon- } \\
\text { tamination }\end{array}$ & $\begin{array}{c}1 \mathrm{M} \mathrm{NaOH} \\
@ 70^{\circ} \mathrm{C} \\
\mathrm{uCi} / \mathrm{ml}\end{array}$ & $\begin{array}{c}3 \mathrm{M} \mathrm{NaOH} \\
@ 70^{\circ} \mathrm{C} \\
\mathrm{uCi} / \mathrm{ml}\end{array}$ & $\begin{array}{c}1 \mathrm{M} \mathrm{NaOH} \\
@ 95^{\circ} \mathrm{C} \\
\mathrm{uCi} / \mathrm{ml}\end{array}$ & $\begin{array}{c}3 \mathrm{M} \mathrm{NaOH} \\
@ 95^{\circ} \mathrm{C} \\
\mathrm{uCi} / \mathrm{ml}\end{array}$ \\
\hline B-101 & $\mathrm{n} / \mathrm{d}$ & $\mathrm{n} / \mathrm{d}$ & $\mathrm{n} / \mathrm{d}$ & & $\mathrm{nm}$ & $\mathrm{nm}$ & $\mathrm{nm}$ & $\mathrm{nm}$ \\
\hline BX-110 & 1.64 & 1.41 & $2.3 \mathrm{E}-01$ & 86 & $\mathrm{~nm}$ & $\mathrm{~nm}$ & $\mathrm{~nm}$ & $\mathrm{~nm}$ \\
\hline BX-112 & 12.8 & 14.4 & 0.6 & 96 & $\mathrm{~nm}$ & $\mathrm{~nm}$ & nm & $\mathrm{nm}$ \\
\hline S-101 & 13.7 & $\mathrm{n} / \mathrm{d}$ & 13.8 & 99 & $4.4 \mathrm{E}-05$ & $\mathrm{n} / \mathrm{d}$ & $1.6 \mathrm{E}-04$ & $\mathrm{n} / \mathrm{d}$ \\
\hline
\end{tabular}

\section{$5 \quad$ Analytical Directions}

Based on the evidence of studies presented above, it is apparent that more effort is required for sample preparation, method reliability, inter-comparisons of methods, and potentially other analytical techniques. Some of the Hanford waste sample matrix types to date have challenged the reliability of existing 222-S methods. In general, the methods are sufficient for aqueous and aqueous/organic supernate matrices, provided that current oxidation steps are followed. However, reliability and inter-method agreement has not been robust for solids and sludges from the high level aged wastes. There are chemistry concerns ranging from the initial sample preparation to the final isolated material measurement. Some of the key issues are discussed here.

\subsection{Dissolution Methods}

Several methods are in use at 222-S laboratory for general preparation of samples. For water soluble species, a simple water leach is used (Anastos, 1999). For more complete dissolution of solid matrices, two options are available, an acid digest with $\mathrm{HNO}_{3}, \mathrm{HCl}$, and $\mathrm{H}_{2} \mathrm{O}_{2}$ (Anastos, 1999 and EPA, 1996), and a potassium hydroxide (KOH) fusion (Fitzgerald, 1998).

Recognizing the limited utility of the water leach, the focus on solids dissolution is for acid digest or $\mathrm{KOH}$ fusion. The acid digest is visually successful, but generates a new matrix which is not always desirable. For example, the use of hydrochloric acid introduces high chloride ion concentration which may conflict with many other methods based on a nitric acid matrix. However, $\mathrm{HCl}$ is needed for effective dissolution of iron based sludges. This is evidenced by visual inspection of the process for $\mathrm{C}-104$ sludge which showed that the $\mathrm{HCl}$ was required to 
obtain a clear solution. In the case of $\mathrm{Tc}$, it has been reported (Cotton, 1962) that $\mathrm{HCl}$ can cause Tc to reduce from the pertechnetate form. This affect is currently uncertain, but could be a factor with the time instability shown for the C-104 sludge analysis. In support of acid digest, the detection limits and ease of use for ICP/MS are positive factors. However, for the sludge material, the intercomparison for the two main methods has not been successful on the limited number of samples to date (AX-104 and C-104). Based on the observation that plutonium contamination can be found in the Aliquat 336 extractant, these methods should become consistent with further improvement in the radchem method.

The $\mathrm{KOH}$ fusion provides a robust but destructive process for bringing the tank sludges into solution. This type of preparation is designed for solid materials, in particular soils. The $\mathrm{KOH}$ fusion has typically been used for dissolving silicate rocks and minerals. In tank waste, it will attack silicate materials and metathesize acid insoluble metal fluorides, sulphates and phosphates into more acid soluble hydroxides. The typical fusion uses $5 \mathrm{~g}$ of $\mathrm{KOH}$ which results in a final potassium concentration of about $20 \mathrm{~g} / \mathrm{l}$. For ICP/MS, the resulting prepared sample must be significantly diluted to less than $0.1 \mathrm{~g} / \mathrm{l}$ in order to avoid over driving the instrument's sensitivity due to the added salts. The required degree of dilution causes reduction in sensitivity. The processing of the $\mathrm{C}-104$ sludges by $\mathrm{KOH}$ fusion made ${ }^{99} \mathrm{Tc}$ undetectable in comparison to radchem for the same stock. With regard to the $\mathrm{C}-104$ sludge, radchem fusion results exhibited instability in results comparable to the acid digest. The cause of the instability is not understood and should be investigated further for these types of samples.

\subsection{Environmental Samples}

Environmental samples typically do not have the radionuclide interference challenges of the high level nuclear wastes. Technetium preparation methods using modern filter and ion exchange media such as TEVA resin (Kaye, 1995) or Rad Disk ${ }^{4}$ (Iwatate, 1997) filters are currently used. To date, the Waste Sampling and Characterization Facility (WSCF) has shown good success on direct analysis of environmental aqueous samples. For various environmental solids, only acid leach preparation procedures are in use. This is based on an assumption that the ${ }^{99} \mathrm{Tc}$ should be deposited on surfaces rather than incorporated into the solid matrix. In all cases, matrix spikes are the primary quality control which may be questionable based on the more extreme situations discovered in high level nuclear wastes. Only limited consideration is given for the possibility that a soluble non-extractable complex form may be present. As more is understood regarding the behavior of environmental Tc, investigations into the robustness of environmental methods may be required.

${ }^{4} \mathrm{Rad}$ Disk is a tradmark of $3 \mathrm{M}$ Corporation. 
HNF-5309, Rev 0. October 20, 1999

\subsection{High Level Tank Supernates}

\subsubsection{Aqueous Supernates}

Measurements of ${ }^{99} \mathrm{Tc}$ have been in aqueous supernates for most of the Hanford chemical processing history, Indeed, analytical development was dominated by work on these fresh materials, including later development for supernates with organic complexes (Metcalf, 1984). The cited literature shows good analytical performance with ever improving separation factors. The Hanford process support laboratories relied then and now on ${ }^{99} \mathrm{Tc}$ spike and standards performance to assure correct results. Since all the methods use oxidation steps to measure total $\mathrm{Tc}$ as $\mathrm{Tc}$ (VII), little evaluation in the context of speciation can be made. Only recently has an alternative technology, ICP/MS, become available for confirming radchem analyses. Even though comparison data for non-complexed supernates are generally good, these materials should be included in any attempts to confirm inter-method and inter-laboratory consistency.

\subsubsection{Organic Supernates}

The inter-comparison work performed on aged Hanford high level wastes containing organic complexants showed discrepancies in results (Table 4; Schroeder, 1995; Fadeff, 1996). A key confirmation was that the aged complexed waste contains species that do not readily release Tc for extraction as the free pertechnetate (Troyer, 1998). While the solution was to simply apply heated hydrogen peroxide in the 222-S procedure (Relyea, 1999), little effort has been made to fully understand the mechanisms of the process. Additional work in this area is needed such that the chemical forms and potential problems are understood as more requests for these measurements are made. Knowledge about the species is expected to assist in development of treatment processes and risk models.

\section{$5.4 \quad$ Tank Sludges}

As noted, only a limited amount of data has been generated on the performance of $\mathrm{Tc}$ analysis for aged tank sludges. These materials by nature are precipitates with high iron or aluminum content. The sample preparations are difficult, resulting in matrices that either have high salt ( $\mathrm{KOH}$ fusion) or high acid mix. All that has been confirmed to date is that data between methods do not correlate, and reliability of the 222-S chemical separation is suspect. Significant additional effort is required to determine what is causing the bias between methods. Accurate analyses of these sludges will be important to evaluating the Privatizaton HLW treatment process.

\subsection{Method Support}

A process support or production based laboratory such as 222-S requires methods that are low cost and reliable. Exhaustive procedures to assure conditioning and isolation of $\mathrm{Tc}$ for reference basis are necessary and have been shown to be of great benefit (Schroeder, 1995; Fadeff, 1996). 
HNF-5309, Rev 0. October 20, 1999

However, the quicker methods based on simple preparation and extraction or ICP/MS are more desirable provided reliability is assured. The ICP/MS is a very attractive method due to its rapid response. The radchem separation methods provide large dynamic range and goog sensitivity for unusual matrices. It is recommended that development continue in these areas with particular emphasis on matrix issues and inter-comparison support.

\subsection{Tracers and Spikes}

It is noted above that most of the development and performance check work is based on using

${ }^{99} \mathrm{Tc}$ as a spike or tracer. Since this material is an external performance monitor of the same analyte, analytical technique within a single aliquot is not completely tracked.A better choice would be the use of ${ }^{95} \mathrm{Tc}$ as a true and non-confounding tracer. The number of chemical manipulations would be reduced with the elmination of a spike-duplicate. Drawbacks are that the half life is short $(61 \mathrm{~d})$ and additional gamma measurements on the isolated Tc are required. The short half life makes supply a challenge, and for this reason, it has not been used at 222-S.

\section{$6 \quad$ References}

Anastos, H. L., Water Leach Sample Preparation, LA-504-101, Rev. G1, Waste Management Hanford Co., Richland WA, January 25, 1999.

Anastos, H. L.,Acid Digestion of Waste Tank Samples for Inductively Coupled Plansm (ICP), LA-50505-163, Rev. B1, Waste Management Hanford Co., Richland WA, June 26, 1999.

Campbell M. H., 1963, Separation of Technetium from Mixed Fission Products by Solvent Extraction with Tributyl Phosphate, Analytical Chemistry, Vol.35, page 2052, December 1963.

Campbell M. H. 1966, Internal Letter to J. V. Panesko, December 12, 1966, Analysis for Technetium-99, Isochem Inc., Richland, Washington.

Cotton, F. A., and G. Wilkinson, Advanced Inorganic Chemistry - A Comprehensive Text, Interscience Publishers, John Wiley \& Sons, 1962, p. 806.

Crawford, B. A., 1998a, Tank 241-AX-104 Residual Solids Leach Test Results, TWR-3548, Rev. 0., Numatec Hanford Corporation for Fluor Daniel Hanford Inc., Richland, Washington.

Crawford, B. A., 1998b, Completion of Waste Minimization Database for LQAMS Screening, internal memorandum 8C520-AT98-009 to S. C. Howald and D. S. Merry, Numatec Hanford Corporation for Fluor Daniel Hanford Inc., Richland, Washington. 
HNF-5309, Rev 0. October 20, 1999

EPA, 1996, Test Methods for Evaluating Solid Waste: Physical/Chemical Methods, SW-846, Rev. 3, U.S. Environmental Protection Agency, Washington, D.C.

Esch, R. A., Tank Waste Remediation System (TWRS) Privatization Contractor Samples Waste Envelope D Material 241-C-106, HNF-SD-WM-DP-225, Rev. 1, Rust Federal Services of Hanford, Inc., April 1997.

Fadeff, S. K., letter report to D Blanchard, "Technetium Oxidation Comparisons", Pacific Nortwest National Laboratory, Richland WA, April 1996.

Fitzgerald, S. L., Fusion by Alkali Metal Hydroxide, LA-549-141, Rev. G0, Waste Management Hanford Co., Richland WA, March 3, 1998.

Iwatate, K., Determination of Technetium-99 by Rad Disk Filtration and Liquid Scintillation Counting, LA-438-402, Rev. A0, Waste Management Hanford Co., Richland WA, September 30, 1997.

Lumetta, G. J., et al, Washing and Caustic Leaching of Hnaford Tank Sludge: Results of FY 1998 Studies, PNNL-12026, Pacific Nortwest National Laboratory, Richland WA, December 1998.

Kaye, J. H., ${ }^{99}$ Technetium Analysis by Extraction Chromatography Using TEVA-Resin, LA-433401, Rev. A0, Waste Management Hanford Co., Richland WA, October 10, 1995.

Metcalf, S. G., 1984, Determination of Technetium-99 in Complexed Hanford Defense Waste, SD-RE-LB-001, Rockwell Hanford Operations, Richland Washington.

Relyea, J. A., "Determination of Technetium-99 Solvent Extraction and Liquid Scintillation Counting", LA-438-101, Rev. E2, Waste Management Hanford Co., Richland WA, January 1998.

Roberts, F.P., "Summary of Research on Tc, Rh, and Pd by Battelle Northwest", USAEC Report, BNWL-B-49, 1971.

Schroeder, N. C., et al, "Technetium Partitioning for the Hanford Tank Waste Remediation System: Anion Exchange Studies for Partitioning Technetium from Synthetic DSSF and DSS Simulants and Actual Hanford Wastes (101-SY and 103-SY) Using Reillex ${ }^{\mathrm{TM}}-\mathrm{HPQ}$ Resin", Los Alamos National Laboratory, LA-UR-95-4440, 1995.

Smith H. E., 1974, Internal Letter to A. L. Case, November 14, 1974, Technetium Determination in Boiling Waste - 1970 Analytical Work, Atlantic Richfield Hanford Company, Richland, Washington. 
HNF-5309, Rev 0. October 20, 1999

Troyer, G. L.,.Internal Letter *C520-AT98-012 to C. M. Seidel, The Analysis of ${ }^{99}$ Tc in Aged Organic Complexants in Hanford Defense Nuclear Waste Tanks, September 29,1998. 


\section{DISTRIBUTION SHEET}

To: Distribution

From: GL Troyer

Date: 10-29-1999

EDT No.

626586

Project Title/Work Order

Survey of Technetium Analytical Production Methods Supporting Hanford Nuclear Materials Processing, HNF-5039, Rev. 0.

CENTRAL FILES B 1-07

PROJECT FILES R1-41

DOE READING ROOM H2-53

C. A. Babel H6-68 DOE

K. M. Thompson H0-12 DOE

J. F. Thompson, Jr. H6-60 DOE

R. M. Yasek S7-54 DOE

F. J. Anderson

H0-22 LMH

J. H. Baldwin R3-73 LMH

T. W. Crawford R3-73 LMH

C. C. Haass H6-64 LMH

T. E. Jones HO-22 LMH

A. J. Knepp H0-22 LMH

S. G. Mckinney R2-12 LMH

T. T. Tran R2-12 LMH

R. A. Watrous R3-75 LMH

E. Tchemitcheff H0-34 NHC

S. A. Catlow T6-50 NHC

R. A. Kirkbride R3-73 NHC

L. L. Lockrem T6-07 NHC

G. L. Troyer T6-50 NHC

W. I. Winters T6-50 NHC

N. G. Colton K2-12 PNL

J. L. Kovach H6-61 ORP-BAT

R. J. Serne K6-81 PNL

M. J. Truex K2-10 PNL

R. A. Jones T6-50 WMH

J. F. Relyea T6-50 WMH

C. M. Seidel S3-30 WMH

KD wiemess $H 6-61$ PNL 